\title{
Os papilomavírus humanos - HPV: histórico, morfologia e ciclo biológico
}

\author{
Geni N. N. de Lima Camaral \\ Márcio Rojas Cruz ${ }^{2}$ \\ Verônica Sales Veras ${ }^{3}$ \\ Cláudia Renata F.Martinst
}

\begin{abstract}
RESUMO - Os papilomavírus são patógenos responsáveis pelo desenvolvimento de tumores benignos e malignos de pele e de mucosas. Pertencem à família Papillomaviridae, gênero Papillomavirus, espécie Human papillomavirus - HPV, que corresponde a uma das oito espécies incluídas no gênero. Os HPVs são classificados em genotipos, com base na comparação de seqüências do gene L1. Seu genoma circular, com cerca de 8.000 pares de bases, é formado por duas fitas de DNA, com oito genes e uma região não codificadora, de controle da origem da replicação e da expressão dos genes reguladores da transcrição. Os HPVs infectam inicialmente as células da camada profunda. Seu genoma pode ficar sob a forma circular (epissomal), dentro do núcleo da célula ou sofrer ruptura na região de E2 e se integrar ao DNA celular. Essa integração tem consequiências na produção de outras proteínas precoces do vírus e que são responsáveis pela transformação celular.
\end{abstract}

Palavras-chave: papilomavírus humanos, HPV, morfologia, ciclo biológico, revisão.

\section{Human papilomavirus - HPV: historic, morphology and biological cicle}

\begin{abstract}
The Human papilomavírus, pathogens responsible for developing benign and malignant tumours of skin and mucosas in humans, belong to the Papillomaviridae family, genus Papillomavirus, and correspond to one among eight species included in this genus. The HPVs are further classified in genotypes, based in the comparison of L1 gene sequences. The double-stranded circular DNA genome, with approximately 8,000 base pairs, includes eight to ten genes and a non-coding region that controls the origin of replication and expression of transcription regulatory genes. Early, in HPVs' cycle, they infect the basal cells of
\end{abstract}

\footnotetext{
${ }^{1}$ Bióloga, Mestrandaem Ciências da Saúde, UnB.

${ }^{2}$ Biólogo, Mestrandoem Biologia Molecular, UnB

${ }^{3}$ Estudante de Biologia, UnB

${ }^{4}$ Professora Doutora do Departamento de Biologia Celular, UnB, CEP 70.919-970 
squamous epithelium. The circular genome can be found in the cell nucleus as an episome or may suffer rupture at the $\mathrm{E} 2$ region and be integrated in celular DNA, resulting in the overexpression of early protein, responsible for cellular transformation.

Keywords: human papilomavírus, HPV, morphology, biological cycle, revision.

Muitas doenças que hoje sabemos serem causadas por vírus têm sido descritas desde a Antiguidade. Entretanto, somente no século XX, a ciência e a tecnologia desenvolveram métodos e instrumentos que permitiram identificar e caracterizar esses patógenos, demonstrando, in vitro ou in vivo, sua capacidade de infectar, reproduzir-se e transmitir-se de uma célula hospedeira a outra, por mecanismos bastante diversificados. A compreensão desses mecanismos é fundamental para o diagnóstico, tratamento, prevenção e controle das doenças virais. Além disso, é Latim, De Medicina, baseada em textos gregos, descreveu as verrugas palmares, plantares e genitais, indicando como eliminá-las com a aplicação de cinzas da borra do vinho (Celsus, 1961). Galeno (129-199 d. C.) também fez observações sobre práticas populares de eliminar verrugas (Doorbar, 1999). Ainda no primeiro século da era Cristã, Martialis, poeta satírico romano, de origem hispânica, em sua Epigrammata Medicae Philosophicae, referiu-se metaforicamente aos condilomas acuminados, as verrugas genitais, em um trecho de poema, citado por J. D. Oriel no capítulo Genital Warts do livro Diseases in the Homosexual Male, organizado por M. W. Adler (1988). Aparentemente, as verrugas genitais eram bastante comuns e os médicos gregos e romanos foram os primeiros a observar a transmissão sexual dessas lesões. Naquela época, o enfoque era dado à descrição dos sinais, dos sintomas e do tratamento das doenças, mas suas causas eram desconhecidas.

Somente no final do século XIX foi registrada a natureza infecciosa das verrugas. Em 1891, Joseph F. Payne, em Londres, publicou um artigo clássico: On the contagiousness of commom warts, onde descreve o desenvolvimento, por auto-inoculação, de verrugas em seu próprio polegar, depois de ter raspado a superfície de uma lesão verrucosa de uma criança. Pouco tempo depois, em 1894, em trabalhos independentes, C. Licht e Gaston Variot, também demonstraram o caráter infeccioso daquelas lesões, provocando o aparecimento de verrugas em voluntários inoculados, experimentalmente, com macerados de tecido verrucoso (Garfield, 1988).

No início do século XX, G. Ciuffo foi o primeiro a suspeitar que as verrugas eram causadas por vírus. Em seu experimento, usou um filtrado, que havia 
sido passado em poros incapazes de reter partículas com dimensões compatíveis com as dos vírus, para auto-inocular-se e produziu verrugas na mão. Em 1933, Richard E. Shope, do Departamento de Patologia Animal e Vegetal, do Instituto Rockefeller para Pesquisa Médica, em Princepton, Nova Jersey, descobriu que os papilomas podiam ser transmitidos de coelhos selvagens, os rabo-de-algodão (cottontail rabbits), aos coelhos domésticos por meio de filtrados livres de células. Descobriu também que o agente causador desses tumores era um vírus, muito semelhante ao que produzia os papilomas em homens, em bois e em cachorros e o denominou de papilomavírus. Em 1935, Peyton Rous e J. W. Beard, do Instituto Rockefeller para Pesquisa Médica, em Nova Iorque, observaram que os papilomas de Shope - tumores epiteliais benignos de coelhos, causados por vírus - podiam tornar-se malignos, progredindo para carcinomas escamosos (Garfield, 1988).

A utilização da microscopia eletrônica - a partir da década de 1930 - e do cultivo de células - na década de 1940 - possibilitou um grande avanço na virologia. Em 1949, Maurice Strauss e outros pesquisadores da Escola de Medicina da Universidade de Yale, New Haven, Connecticut, usando um microscópio eletrônico, observaram partículas semelhantes aos vírus em amostras retiradas de papilomas da pele. Um ano mais tarde, Strauss e colaboradores identificaram o papilomavírus humano - HPV - como o agente etiológico das verrugas (Garfield, 1988).

Apesar do conhecimento de que outros membros do grupo dos papilomavírus eram carcinogênicos em coelhos e também capazes de transformar alguns tipos de células de roedores (zur Hausen \& De Villiers, 1994), não havia sido estabelecida, até a década de 1970, uma correlação entre o HPV e o carcinoma cervical humano. A partir do final da década de 1970, foram identificados diversos tipos de HPV em várias lesões de pele e de mucosas - verrugas, displasias epiteliais e carcinomas de cérvice uterina e de pênis, o que reforçou a importância médica do HPV (Doorbar \& Sterling, 2001). Na década de 1980, o isolamento de tipos específicos de HPV em biópsias de câncer cervical abriu caminho para estudos detalhados do papel desses vírus nos cânceres genitais (zur Hausen \& De Villiers, 1994). Também nessa época, a descoberta de que a linhagem celular HeLa - ori-

ginada de um carcinoma cervical e cultivada desde a década de 1950 - continha DNA de HPV integrado e transcrito ativamente, aumentou o interesse no estudo desses vírus. Atualmente, fortes evidências de estudos epidemiológicos, clínicos e de biologia molecular permitem afirmar que, na maioria, os cânceres genitais são doenças sexualmente transmissíveis, causadas por certos tipos de papilomavírus humanos (Doorbar \& Sterling, 2001). 


\section{Taxonomia e nomenclatura}

A taxonomia e a nomenclatura dos vírus são elaboradas por um comitê internacional de taxonomia viral - The International Comittee on Taxonomy of Viruses - ICTV - da Divisão de Virologia, da União Internacional de Associações de Microbiologia. Os papilomavírus são vírus de DNA de dupla fita (dsDNA) que infectam vertebrados. Até o sexto relatório publicado, em 1995, por esse comitê, os gêneros Papillomavirus e Polyomavirus constituíam a família Papovaviridae (Murphy et al., 1995). A partir do sétimo relatório (van Regenmortel et al., 2000), foi criada a família Papillomaviridae, na qual passou a ser incluído o gênero Papillomavirus. Nesse gênero são descritas oito espécies e entre elas está a espécie Human papillomavirus (HPV). Ainda segundo esse último relatório do ICTV, há 82 genotipos de HPV descritos na literatura. Entretanto, há outros tipos cuja identificação ainda é incerta.

O nome papilomavírus foi composto do latim papila, diminutivo de papula, projeção ou saliência em forma de mamilo e da desinência -oma, usada pelos antigos médicos gregos para designar as tumorações ou os entumescimentos. As espécies de papilomavírus são nomeadas de acordo com o grupo de animais que eles infectam, seguindo uma nomenclatura binominal, em inglês: Bovine papillomavirus (BPV), Canine papillomavirus, Cottonnail rabbit papillomavirus, Deer papillomavirus, European elk papillomavirus, Human papillomavirus e Ovine papillomavirus (van Regenmortel et al.., 2000).

À medida que diferentes tipos de HPV foram sendo descobertos, receberam números sequienciais como, por exemplo: HPV-6, HPV-11, HPV-16 e HPV18. A classificação em sorotipos não é aplicada aos HPVs. Testes de neutralização, que permitem a distinção entre sorotipos de vírus, não podiam ser realizados com os HPVs pela dificuldade em cultivá-los em células, por isso sua classificação é feita com base nas diferenças do próprio genoma. Assim, os tipos são genotipos e não sorotipos (White \& Fenner,1994). A classificação atual dos HPVs em tipos baseia-se na comparação de sequiências de nucleotídeos do gene L1 dos diversos HPVs. Cada tipo de HPV difere dos outros tipos em pelo menos 10\% na seqüência de nucleotídeos de L1. (Doobar \& Sterling, 2001; Burk, 1999). Quando essa homologia varia menos do que $2 \%$, fala-se em variante e, entre $2 \%$ e $10 \%$, em subtipo (Burk, 1999).

As relações filogenéticas entre os tipos de HPV, com base na variação de seqüências em uma dada região do genoma, permitem interpretar como os diferentes tipos e subtipos evoluíram. A construção, com o auxílio de softwares especializados, de árvores filogenéticas dos papilomavírus humanos e de outros animais, tem mostrado que a classificação genômica tem uma correlação com o 
Quadro 1. Tipos mais comuns de HPV em lesões da pele e mucosa anogenital

Tipos de lesões

Tipos mais comuns de HPV

Benignas da pele

$$
-1,2,3,4,10
$$

Benignas da mucosa anogenital

$-6,11,40,42,43,44,5356,66,68$

Malignas da mucosa anogenital

$-16,18,31,33,35,39,45,51,52,58$

Fonte: modificado de DOORBAR, J.; STERLING, J.C., 2001.

tropismo por um tipo específico de epitélio (pele ou mucosa) e com o tipo de lesão (benigna ou maligna) produzida pelo vírus (Doorbar \&Sterling, 2001) (Quadro1)

\section{Morfologia, estrutura e composição da partícula viral}

A partícula viral, o vírion, consiste de uma capa protéica, o capsídeo, que envolve o genoma viral (Figura 1). Os papilomavírus são pequenos vírus nãoenvelopados, arredondados, com diâmetro em torno de $55 \mathrm{~nm}$, quando observados com contrastação negativa, por microscopia eletrônica (Doorbar \&Sterling, 2001). Seu capsídeo, com aproximadamente $2 \mathrm{~nm}$ de espessura, é composto por 72 unidades morfológicas, os capsômeros, dispostos segundo uma simetria icosaédrica $(\mathrm{T}=7)$. Os capsômeros, localizados em cada um dos 12 vértices, são pentavalentes, isto é, circundados por cinco capsômeros adjacentes, e os outros 60 capsômeros são hexavalentes (Baker et al., 1991). Os 72 capsômeros são pentâmeros da proteína estrutural principal, L1 $(54 \mathrm{kDa})$. Uma outra proteína estrutural menos representada, a L2 (76 kDa), também compõe mais internamente o capsídeo. Essas proteínas são responsáveis pela imunogenicidade do vírus e carregam determinantes antigênicos gênero-específicos. Um estudo sobre a estrutura do capsídeo do Bovine papillomavirus, BPV, de Trus et al., 1997 (apud Booy et al., 1998), sugeriu que a proteína L2 pode estar localizada, nos vértices $5 \mathrm{X}$, no centro dos capsômeros pentavalentes. A proporção molar entre as prote- 
ínas L1 e L2 é de 30:1, quando são co-expressas in vitro ou quando extraídas de lesões naturalmente produzidas pelo BPV-1 (Booy et al., 1998).

O genoma da partícula viral (Figura 2) é formado por duas fitas circulares de DNA, com cerca de 8.000 pares de bases (pb), ligadas covalentemente e associadas a histonas de origem celular. O genoma possui oito genes na região não codificadora, também chamada região longa de controle - long control region, $\mathrm{LCR}$, ou upstream regulatory region, URR - localizada em uma das fitas. A região LCR contém elementos reguladores da origem da replicação e da expressão de genes reguladores da transcrição viral (Boy et al., 1998). Embora ocorram variações no tamanho e na seqüência dos genes e das LCRs entre os diferentes papilomavírus, todos têm a mesma organização genômica.

A região precoce $\mathrm{E}$ (de early region) codifica várias proteínas - E1, E2, E4, E5, E6 e E7 - que regulam a transcrição e a replicação viral e controlam o ciclo celular, conferindo a esses vírus potencial para transformar e imortalizar as células hospedeiras. Nos BPVs são ainda identificadas duas outras ORFs, E3 e E8 (Doorbar \& Sterling, 2001). Na região chamada tardia L (de late region), localizam-se os genes L1 e L2. Esses genes têm seqüências altamente conservadas em todos os papilomavírus (Bernard et al., 1994).

\section{O ciclo biológico dos HPVs}

Os papilomavírus são espécie-específicos e têm tropismo pelo epitélio escamoso da pele e das mucosas. Além disso, os diversos tipos que infectam uma determinada espécie mostram uma tendência a se instalar em regiões preferenciais do organismo, como, por exemplo, mãos, pés, mucosa oral ou genital. O tipo de lesão que se desenvolve também está associado ao tipo do vírus. Em humanos, por exemplo, os HPVs 1, 2 e 4 causam geralmente verrugas comuns nas mãos e nos pés. Os HPVs 6 e 11 causam verrugas genitais e os HPVs 16 e 18 são encontrados em neoplasias intraepiteliais cervicais (NIC) e em carcinomas escamosos de colo do útero e de pênis.

O ciclo biológico dos HPVs na pele ou mucosas (Figura 3) tem início quando as partículas virais penetram nas células da camada profunda, que são as células menos diferenciadas do epitélio escamoso, e que ainda têm atividade mitótica. Fissuras nesse epitélio possibilitam o acesso do vírus a essas células. $\mathrm{O}$ vírion viral entra na célula pela interação das proteínas do capsídeo com receptores específicos da superfície celular. Estudos in vitro apontaram para a alfa-6 integrina como um receptor celular para os papilomavírus (Evander et al., 1997; McMillan et al., 1999). Depois de penetrar na célula, o vírion perde seu capsídeo, expondo seu DNA à ação de enzimas nucleares, o que favorece a expressão dos genes virais. 
Após a infecção, o vírus passa por um período de incubação de 2 a 3 semanas, antes que se inicie o desenvolvimento de lesões (Oriel, 1971). O DNA do HPV pode permanecer quiescente na célula, antes ou depois de uma infecção produtiva. O HPV-16 já foi detectado por PCR (polymerase chain reaction) em amostras de tecido cervical de 5\% a 40\% de mulheres sem evidências clínicas ou histológicas de infecção por esse vírus (Hildesheim, Schiffman \& Gravitt, 1994; Syrjännen et al., 1990).

O genoma pode ficar, dentro do núcleo da célula, sob a forma circular, não integrado ao genoma celular (forma epissomal). Nos estágios precoces da infecção, o DNA epissomal replica-se, na camada basal, concomitantemente ao DNA celular, gerando de vinte a cinqüenta cópias por célula. Nas infecções por tipos de HPV associados a cânceres cervicais é observada, com freqüência, a integração do DNA do vírus a um cromossomo do hospedeiro (Villa, 1997), pela ruptura na região de E2 (Doorbar \& Sterling, 2001). As conseqüências da ruptura de E2 no mecanismo de carcinogênese serão discutidas no artigo HPV: Carcinogênese e imunogênese.

Estudos da transcrição viral em linhagens de queratinócitos humanos, imortalizados por HPV-16 (Doorbar et al., 1990; Rohls et al., 1991), mostraram que os genes precoces são transcritos a partir de promotores, por splicing diferencial. Assim, vários RNAs são produzidos a partir de promotores diferentes.

As proteínas traduzidas a partir desses RNAs mensageiros vão interferir na função de proteínas celulares que controlam o ciclo normal da célula, a diferenciação celular e a apoptose. A proteína E7 estimula a proliferação dos queratinócitos infectados, por sua ligação com fatores de transcrição AP1, levando à ativação de promotores que respondem à AP1. Outro mecanismo pelo qual E7 atua na proliferação celular é por sua associação com a pRb (proteína de suscetibilidade ao retinoblastoma), que é um regulador negativo do ciclo celular na passagem de G1 para S. A proteína E6 também interfere na regulação do ciclo celular ao ligar-se a uma proteína celular supressora de tumor e induzir a degradação de p53 (Storey et al.., 1998). Nos HPVs de alto risco, entretanto, a ação de E6, para a degradação de p53, é muito mais eficiente. A inibição da atividade das proteínas Rb e p53 é uma característica de outros vírus que induzem a formação de tumores como os adenovírus, os poliomavírus e alguns herpesvírus (Doorbar \& Sterling, 2001). A proteína E5 também apresenta atividade transformante, que será descrita no artigo HPV: Carcinogênese e imunogênese, bem como os mecanismos de carcinogênese dos HPVs.

No estágio produtivo do ciclo viral, a expressão de E7 parece reativar o mecanismo celular de replicação de DNA, para que ocorra a amplificação do genoma viral (Flores et al., 2000), que irá compor novos vírions. A proteína E1, que tem 
atividade de helicase (Yang et al., 1993), parece iniciar a replicação do epissoma viral. Além disso, uma proteína $\mathrm{E} 1{ }^{\wedge} \mathrm{E} 4$, produzida a partir de um RNA transcrito de um pequeno trecho $\mathrm{C}$ - terminal de $\mathrm{E} 1$ se funde com um transcrito de $\mathrm{E} 4$, precedendo a síntese das proteínas do capsídeo. Estudos sugerem que sua função pode ser a de facilitar a produção de vírus, talvez pela inibição da apoptose, ou pelo e stímulo à replicação do DNA viral. A associação de E1^E4 com filamentos intermediários do citoesqueleto, quando expressa in vitro, tem sugerido seu papel na liberação do vírus, por aumentar a fragilidade das células infectadas (Doorbar et al., 1991).

As proteínas L1 e L2, depois de sintetizadas no citoplasma, são direcionadas para o núcleo da célula, onde ocorre a montagem das novas partículas (Villa, 1997), nas camadas mais superficiais do epitélio. A proteína L2 não é essencial para a formação do capsídeo in vitro (Hangensee, Yaegashi \& Gallway, 1993); entretanto, estudos sugerem que essa proteína tem papel importante no empacotamento do DNA viral ou na montagem da partícula viral (Doorbar \& Sterling, 2001), uma vez que a formação do capsídeo aumenta 100 vezes na presença de L2 in vitro (Hangensee, Yaegashi \& Gallway, 1993). A liberação das partículas virais ocorre na superfície da lesão, durante a descamação celular.

\section{Considerações finais}

O número de publicações, relacionadas pela base de dados Medline sobre papilomavírus humanos e sua associação ao câncer cervical passou de uma centena, no início da década de 1980, a cerca de setecentas em 2000. No número crescente de trabalhos publicados, nos anos 1980, foi demonstrada a prevalência de DNA de HPV nos cânceres cervicais e era relatada a validade dos métodos de detecção disponíveis. O decênio de 1990 produziu resultados esclarecedores sobre o papel de certos tipos de HPV na carcinogênese, por estudos de coorte e casoscontrole e, no final daquela década, houve um aumento do número de publicações sobre as aplicações clínicas dos testes de HPV (Bosch et al., 2002).

Apesar de todo o progresso conquistado nas últimas duas décadas sobre o conhecimento dos papilomavírus humanos, seu inequívoco papel no desenvolvimento do carcinoma escamoso de colo uterino e as fortes evidências de sua participação no câncer de pênis, a incidência dessas doenças é muito elevada nos países em desenvolvimento, quando comparada aos dados de países desenvolvidos. 


\section{Referências bibliográficas}

ADLER, M.W. Diseases in the Homosexual Male. Londres, Springer-Verlag, p. 99-109, 1988.

BAKER, T.S.; NEWCOMB, W.W.; OLSON, N.H.; COWSRT, L.M.; OLSON, C. BROWN, J.C. Structures of bovine and Human papillomavirus. Analysis by cryonelectron microscopy and three-dimensional image reconstruction. Biophys. J. 60: 1445-56, 1991.

BERNARD, H.U.; CHAN, S.Y.; MANOS, M.M.; ONG, C.K.; VILLA, L.L.; DELVIS, H.; PEYTON, C.L.; BAUER, H.M.; WHEELER, C.M. Identification and assessment of known and novel human papillomaviruses by polymerase chain reaction amplification, restriction fragment lenght polymorphisms, nucleotide sequence and phylogenetic algorithms. J. Infect. Dis, 170:1077-85, 1994.

BOOY, .F; RODEN, R.B.S; GREENSTONE, H.L.; SCHILLER, J.T.; TRUS, B.L. Two antibodies that neutralize papillomavirus by different mechanisms show distinct biding patterns at $13 A^{o}$ resolution. J. Mol. Biol. 281: 95-106, 1998.

BOSCH, F.X.; LORINCZ, A.; MUÑOZ, N.; MEYJER, C.J.L.M.; SHAH, K.V. The causal relation between human papillomavirus and cervical cancer. J. Clin Pathol 55: 244$65,2002$.

BURK, R.D. Human papillomavirus and the risk of cancer. Hosp.Pract.: 34:11, Disponível na internet. http://www.hosppract.com/issues/1999/11/burk.htm., 1999, Acesso em 15 abril de 2002.

CELSUS, A.C. De Medicina, v II, livro V, prefácio e tradução de W. G. Spencer. Londres. William Heinemann LTD, Cambridge, Harvard Academic Press, p.161-3, 1991.

DOORBAR, J.; STERLING, J.C. The biology of human papillomaviruses In STERLING, J.C. \& TYING, S.K. (edit), Human papillomaviruses - clinical and scientific advances Londres, Arnold, p. 10-23, 2001.

DOORBAR, J. Warts and all. Mill Hill Essays, Londres. National Institute for Medical Research, Disponível em: http://www.nimr.mrc.ac.uk/MillHill Essays/1999/warts.htm., 1999, Acesso em 26 de fevereiro de 2002.

DOORBAR, J.; PARTON A.; HARTLEY. K.; BANKS, L.; CROOK, T.; STANLEY, M. Detection of novel splicing patterns in a HPV 16-containing keratinocyte cell line. Virology 178: 254-62, 1990.

EVANDER, M.; FRAZER, I.H.; PAYNE, E.; MEY, Q.Y.; HEMGEST K.; MCMILLAN, N.A.J. Identification of the alpha 6 integrin as a candidate receptor for papillomaviruses. J. Virol. 71: 149-56, 1997.

FLINT, S.J.; ENQUIST; L.M. \& KRUG, R.M. Principles of virology-molecular biology, pathogenesis and control. Washington DC, ASM Press, 2000, 804p.

FLORES, E.R.; ALLEN-HOFFMANN, B.L.; LEE, D.; LAMBERT, P.F. The human papilomavirus type $16 \mathrm{E} 7$ oncogene is required for the reproductive stage of the viral 
cycle. J. Virol. 15: 6622-31, 2000.

GARFIELD, E. All sorts of warts - separating facts from fiction. Current contents, 9: 3-11, 1998.

HAGENSEE, M.E.; YAEGASHI, N. \& GALLWAY, D.A. Self-assembly of human papillomavirus type 1 capsids by expression of $L 1$ protein alone or by coexpression of L1 and L2 capsid protein. J. Virol. 67: 313-22, 1993.

HILDESHEIM, A.; SCHIFFMAN, M.H. \& GRAVITT, P. Persistence of type-specific human papillomavirus infection among cytologically normal women in Portland, Oregon. J. Infect. Dis. 169: 235-40, 1994.

MCMILLAN, N.A.; PAYNE, E.; FRAZER, I.H. \& EVANDER, M. Expression of the alpha 6 integrin confers papillomavirus capsid binding upon receptor-negative B-cells. Virology, 261:271-9, 1999.

MURPHY, F.A.; FAUQUET, C.M.; MAYO, M.A.; JARVIS, A,W.; GHABRIAL, S.A. SUMMERS, M.D.; MARTELLI, G.P. \& BISHOP, D.H.L. (org.). The Classification and Nomenclature of Viruses. "Sixth Report of the International Committee on Taxonomy of Viruses”. Archives of Virology, Springer Verlag, Nova Iorque, 1995, $586 \mathrm{p}$.

ORIEL, J.D. Natural history of genital warts. Brit J Vener Dis. 47: 1-13, 1971.

ROHLS, M.; WINCHENBACH S.; MEYER S.; RUPPT. \& DÜRST M. Viral transcription in human keratinocyte cell lines immortalized by human papillomavirus type 16. Virology 183: 331-42, 1991.

STOREY, A.; THOMAS, M.; KALITA, A.; HARDWOOD, C.; GARDIOL, D.; MANTOVANI, F.; BREUER, J.; LEIGH, I.M.; MATLASHEWSHI, G.; BANKS, L. Pole of a 53 polymorphism in the development of human papillomavirus-associated cancer. Nature 393:229-34, 1998.

SYRJÄNEN, S.; SAASTAMOINEN, J.; CHANG, F.; JI, H. \& SYRJÄNEN, K. Colposcopy, punch biopsy, in situ DNA hybridization and polymerase chain reaction in searching for genital human papillomavirus (HPV) infections in women with normal PAP smears. J. Med. Virol 31: 259-66, 1990.

VAN REGENMORTEL, M.H.V.; FAUQUET, C.M.; BISHOP, D.H.L..; CARTENS, E.B.; ESTES, M.K.; LEMON, S.M.; MANILOFF, J.; MAYO, M.A.; MCGEOCH, D.J.; PRONGLE, C.R. \& WICKNER, R.B. (org.). Virus Taxonomy: The Classification and Nomenclature of Viruses. The Seventh Report of the International Committee on Taxonomy of Viruses. San Diego. Academic Press, 2000, 1176 p.

VILLA, L.L. Human papillomavirus and cervical cancer. Adv Cancer Res. 71:321-41, 1997.

WHITE, D.O. \& FENNER, F.J. Medical Virology, San Diego, Academic Press, 1994, 603 p.

YANG, L.; MOHR, I.; FOUTS, E.; LIM, D.A.; NOHAILE, M.; BOTCHAN, M. The E1 protein of bovine papillomavirus 1 is an ATP-dependent DNA helicase. Proc Natl Acad Sci USA 90: 5086-90, 1993.

ZUR HAUSEN, H. \& DE VILLIERS, E.M. Human Papillomaviruses. Annu. Rev. Microbiol. 48: 427-47, 1994. 